\title{
Pengaruh Bahan Ajar Sistem Reproduksi Manusia Terintegrasi Nilai-Nilai Al Qur'an Terhadap Sikap Spiritual Siswa
}

\author{
Syarimansyah $^{1}$, Muhammad Irwansyah ${ }^{2}$ dan Nehru ${ }^{3}$ \\ ${ }^{1}$ Mahasiswa Program Studi Pendidikan Biologi STKIP Bima- NTB \\ ${ }^{2,3}$ Dosen Program Studi Pendidikan Biologi STKIP Bima- NTB \\ m.irwansyah_bio@stkipbima.ac.id
}

\begin{abstract}
ABSTRAK
Penelitian ini bertujuan untuk mengetahui pengaruh bahan ajar sistem reproduksi manusia terintegrasi nilai-nilai Al Qur'an terhadap sikap spiritual siswa. Adapun jenis penelitian yang digunakan yaitu penelitian quasi eksperiment dengan populasi penelitian siswa SMPN 1 Sape Kabupaten Bima - NTB kelas IX tahun pelajaran 2018/2019. Sedangkan instrumen penelitian yang digunakan yaitu instrumen non tes berupa lembar penilaian diri dan lembar observasi. Data hasil penelitian dianalisis dengan menggunakan gain score. Adapun hasil penelitian menunjukkan bahwa penggunaan bahan ajar sistem reproduksi manusia terintegrasi nilai-nilai Al Qur'an dapat meningkatkan sikap spiritual siswa dengan nilai gain score 0,5 tergolong sedang.
\end{abstract}

Kata Kunci: Bahan Ajar, Al Qur'an, Sikap

\section{ABSTRACT}

This study aims to determine the effect of learning tools on the human reproductive system matter integrated with the values of the Quran through the spiritual attitude of students. The research is a quasi-experimental study with the population is SMPN 1 Sape district of Bima- NTB class IX in students in the academic year 2018/2019. The research instruments used were non-test instruments in the form of self-assessment sheets and observation sheets. The data was analyzed by using gain scores test. The results of the study show that the use of learning tools on the human reproductive system matter integrated with the values of the Quran can enhance students' spiritual attitudes with a gain score is 0.5 and classified as good category.

Kata Kunci: Learning Tools, Quran, Attitude 


\section{PENDAHULUAN}

Lahirnya kurikulum 2013 membawa misi utama yaitu untuk menghasilkan insan Indonesia yang produktif, kreatif, inovatif dan afektif melalui penguatan sikap, keterampilan dan pengetahuan yang terintegrasi (Mulyasa, 2013). Dalam pengembangan kurikulum 2013 kementerian pendidikan dan kebudayaan merumuskan 4 kompetensi inti (KI) yang membedakan dengan kurikulum sebelumnya yaitu KI 1 sikap spiritual, KI 2 sikap sosial, KI 3 pengetahuan dan KI 4 keterampilan. Jadi kurikulum 2013 hadir untuk menjawab berbagai permasalahan yang ada salah satunya terkait kemerosotan moral peserta didik.

Namun menurut Makmun (2014) kegiatan pembelajaran ilmu pengetahuan alam (IPA) di sekolah lebih menekankan pada peningkatan kognitif dan hafalan padahal salah satu tujuan dari pembelajaran IPA yaitu meningkatkan nilai keyakinan terhadap tuhan yang maha esa. Niimati \& Mursalin (2018) menambahkan bahwa bahan ajar IPA yang digunakan oleh guru di sekolah belum terlihat mengintegrasikan antara IPA dengan nilai-nilai agama (Al Qur'an) sehingga siswa tidak mendapatkan sesuatu yang bermakna spiritual dari pembelajaran sains yang diajarkan.

Padahal hakikat IPA merupakan gejala-gejala alam pada dimensi pengetahuan (keilmuan) yang dapat dikaitkan dengan dimensi nilai $u k h r a w i$, yakni dengan memperhatikan keteraturan di alam semesta akan semakin meningkatkan keyakinan akan adannya sebuah kekuatan yang Maha dasyat yang tidak dapat dibantah lagi, yaitu Allah SWT (Chandra, 2013).

Salah satu materi IPA yang dipelajari oleh siswa SMP/MTs adalah materi sistem reproduksi manusia. Materi sistem reproduksi manusia ternyata berhubungan dengan ayatayat yang terkandung didalam Al Qur'an misalnya QS Al-Mu'minun ayat 12-14, QS Adzariyat ayat 49, QS Al-isra'a ayat 32, dan QS Al-Hajj ayat 5 (Irwansyah, 2018). Menurut Jamilah (2014) integrasi nilai agama kedalam materi pembelajaran berkontribusi positif menghasilkan manusia yang baik yang mengaplikasikan keterampilan dan pengetahuan sesuai dengan Islam. Begitupun dengan hasil penelitian Agusti (2019) bahwa penerapan modul pembelajaran sistem reproduksi manusia berazaskan nilai Al Qur'an dan Hadis dapat meningkatkan motivasi dan hasil belajar siswa.

Mengintegrasikan antara sains dan nilai-nilai agama bukan hanya sekedar mencari dalil dalam Al Qur'an atau Hadis Nabi, bukan juga proses mengislamisasikan sains tetapi sains harus bisa menjadi jalan atau perantara bagi siswa untuk mendekatkan dirinnya kepada Allah SWT (Hapiz, 2019). Oleh karena itu sudah saatnya guru IPA menyusun ataupun menggunakan bahan ajar yang berorientasi pada nilai-nilai agama (Al Qur'an). Sehingga 
kedepannya lembaga pendidikan mampu menghasilkan insan Indonesia yang memiliki kecerdasan yang utuh baik kecerdasan intelektual, emosional, sosial maupun kecerdasan spiritual.

Urain diatas memotivasi penulis melakukan penelitian dengan judul "pengaruh bahan ajar sistem reproduksi manusia terintegrasi nilai-nilai Al Qur'an terhadap sikap spiritual siswa". Semoga hasil penelitian ini dapat dijadikan rujukan oleh pihak terkait terutama guru dan pemerintah daerah dalam memperbaiki kualitas pendidikan di kabupaten Bima provinsi Nusa Tenggara Barat (NTB).

\section{METODE PENELITIAN}

Jenis penelitian yang digunakan yaitu penelitian quasi eksperiment. Penelitian ini diadakan di SMPN 1 Sape kabupaten Bima- NTB tahun pelajaran 2018/2019. Populasi penelitian adalah seluruh kelas IX. Kemudian dilakukan pemilihan sampel secara purposive sampling dan kelas yang terpilih adalah kelas $\mathrm{IX}_{\mathrm{A}}$ dan $\mathrm{IX}_{\mathrm{B}}$ berjumlah 53 orang. Instrumen yang digunakan berupa lembar penilaian diri dan lembar observasi. Data yang diperoleh dianalisis dengan menggunakan gain score ternormalisasi. Tingkat perolehan Gain Score ternormalisasi dikategorikan ke dalam tiga kategori, yaitu: $\mathrm{g}-$ tinggi jika $(\langle\mathrm{g}\rangle)\rangle 0,7$; $\mathrm{g}-$ sedang jika $0,7 \geq(<\mathrm{g}>) \geq 0,3$; dan $\mathrm{g}-$ rendah jika $(<\mathrm{g}>)<0,3$ (Hake, 1998).

\section{HASIL DAN PEMBAHASAN}

\section{Data Kelas Kontrol}

Kelas kontrol adalah kelas yang diajar tanpa menggunakan bahan ajar sistem reproduksi manusia terintegrasi nilai-nilai Al Qur'an. Bahan ajar yang digunakan hanya berupa buku siswa yang dibeli dipasaran. Adapun yang menjadi kelas kontrol dalam penelitian ini yaitu siswa SMPN 1 Sape kabupaten Bima kelas $\mathrm{IX}_{\mathrm{B}}$ yang berjumlah 26 orang. Adapun data hasil penelitian pada kelas kontrol dapat dilihat pada grafik berikut:

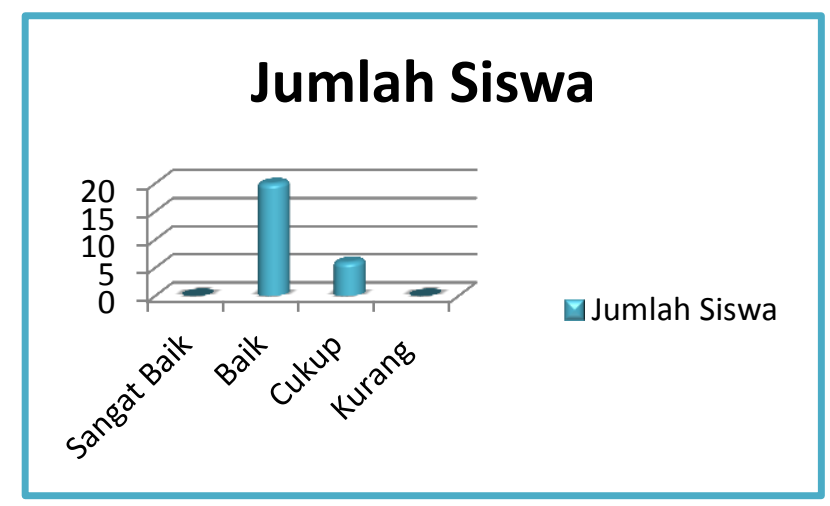

Grafik 1: Data Kelas Kontrol 
Data grafik 1 menunjukkan bahwa skor sikap spiritual siswa yang diperoleh dari hasil penilaian diri dan lembar observasi yaitu sebanyak 20 dari 26 orang siswa menunjukkan sikap spiritual kategori baik. Sedangkan terdapat 6 dari 26 orang siswa menunjukkan sikap spiritual kategori cukup. Sementara itu pada kelas kontrol tidak terdapat siswa yang nilai sikap spiritualnya masuk kategori sangat baik dan juga tidak terdapat siswa yang nilai sikap spiritualnya masuk kategori kurang.

Masih terdapatnya siswa yang sikap spiritualnya masuk kategori cukup disebabkan oleh dua hal (1) model pembelajaran yang digunakan berorientasi pada pengetahuan kognitif dengan mengabaikan peningkatan sikap dan (2) buku siswa yang digunakan cenderung mengasah kemampuan kognitif tanpa ada peningkatan nilai-nilai karakter didalamnya. Hal ini sejalan dengan pernyataan Bahtiar, 2018 yang menyatakan bahwa model pembelajaran digunakan guru disekolah cenderung mengasah kemampuan kognitif sedangkan peningkatan nilai-nilai sikap baik sikap spiritual maupun sikap sosial cenderung diabaikan. Niimati \& Mursalin, 2018 juga menyatakan hal yang sama bahwa bahan ajar IPA yang digunakan oleh guru di sekolah belum terlihat mengintegrasikan antara IPA dengan nilai-nilai agama (Al Qur'an) sehingga siswa tidak mendapatkan sesuatu yang bermakna spiritual dari pembelajaran sains yang diajarkan.

\section{Data Kelas Eksperimen}

Kelas eksperimen adalah kelas yang diajar dengan menggunakan bahan ajar sistem reproduksi manusia terintegrasi nilai-nilai Al Qur'an. Bahan ajar sistem reproduksi manusia terintegrasi nilai-nilai Al Qur'an diadopsi dari bahan ajar yang telah dikembangkan oleh Irwansyah, 2018. Kelas eksperimen dalam penelitian ini yaitu siswa SMPN 1 Sape kabupaten Bima kelas $\mathrm{IX}_{\mathrm{A}}$ yang berjumlah 27 orang. Data hasil penelitian pada kelas eksperimen dapat dilihat pada grafik berikut:

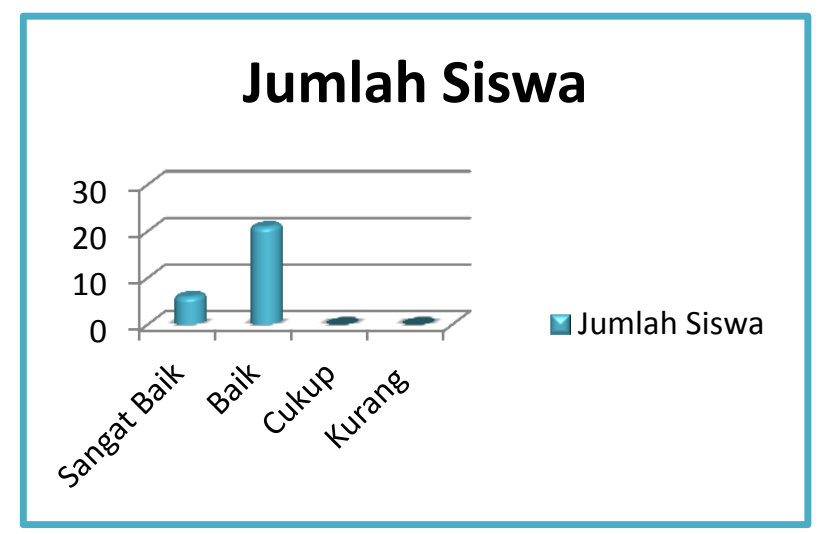

Grafik 2: Data Kelas Eksperimen 
Berdasarkan data grafik 2 diatas menunjukkan bahwa skor sikap spiritual siswa pada kelas eksperimen yang diperoleh dari hasil penilaian diri dan lembar observasi yaitu sebanyak 6 dari 27 orang siswa menunjukkan sikap kategori sangat baik. Sedangkan terdapat 21 dari 27 orang siswa menunjukkan sikap kategori baik. Sementara itu pada kelas eksperimen ini tidak terdapat siswa yang nilai sikap spiritualnya masuk kategori cukup dan kurang.

Adannya peningkatan skor nilai spiritual siswa pada kelas eksprimen yang diajar dengan menggunakan bahan ajar sistem reproduksi manusia terintegrasi nilai-nilai Al Qur'an disebabkan karena penanaman nilai-nilai keagamaan pada mata pelajaran umum dapat mewujudkan sumberdaya manusia berkualitas serta dapat meningkatkan keimanan dan ketaqwaan peserta didik pada tuhan yang maha esa (Salafudin, 2019). Selain itu juga disebabkan karena bahan ajar sistem reproduksi manusia terintegrasi nilai-nilai Al Qur'an memuat permasalahan kontekstual dimasyarakat dan masalah-masalah tersebut dapat diselesaikan dengan berpedoman pada nilai-nilai Al Qur'an. Seperti masalah penyakit HIV/AIDS, gonorea (kencicing nanah), candidias (keputihan). Alzheimer serta aborsi atau penguguran kehamilan diluar nikah.

Penyakit sistem reproduksi seperti yang disebutkan diatas menyerang masyarakat disebabkan karena pergaulan bebas dan seks bebas. Sementara didalam Al Qur'an Allah SWT melarang umatnya untuk melakukan seks bebas. Allah SWT berfirman "Janganlah kalian mendekati zina (seks bebas) karena zina termasuk perbuatan yang keji dan jalan yang buruk" (Qs. Al-Isra'a: 32). Selanjutnya dalam Hadisnya Rasulullah SAW mengancam bagi pelaku zina "Umatku senantiasa ada dalam kebaikan jika tidak terdapat zina namun jika terdapat zina maka Allah SWT akan menimpakkan azab terhadap mereka" (HR. Ahmad). (Irwansyah, 2018).

Melihat kebenaran Al Qur'an dan Hadis Nabi tersebut An-Najjar, 2011 menyatakan pemaparan dan penonjolan dimensi-dimensi ilmiah dalam Al Qur'an merupakan metode dakwah yang paling efektif diera sains dan tekhnologi sekarang ini, disaat manusia begitu terpesona akan sains dan produk-produk tekhnologi. Mereka sangat membutuhkan bukti-bukti empiris yang dapat dinalar dan dirasa yang mengajak dan mengarahkan mereka agar mempercayai kebenaran dan kerasulan Nabi Muhammad SAW.

Penelitian ini didukung juga oleh hasil penelitian Susilowati (2017); Susanti \& Djukri (2018) yang menyimpulkan bahwa penggunaan bahan ajar IPA terintegrasi nilai Islam dapat meningkatkan sikap spiritual dan kemandirian siswa. 


\section{KESIMPULAN}

Kesimpulan dari hasil penelitian ini yaitu penggunaan bahan ajar sistem reproduksi manusia terintegrasi nilai-nilai Al Qur'an dapat meningkatkan skor sikap spiritual siswa dengan rincian 6 dari 27 orang siswa memperoleh nilai sikap spiritual kategori sangat baik. Sedangkan terdapat 21 dari 27 orang siswa menunjukkan sikap spiritual kategori baik. Adapun sikap spiritual siswa yang dinilai dalam penelitian ini yaitu berdoa sebelum dan sesudah pembelajaran, meyakini kebesaran tuhan, mengagungkan kebesaran tuhan, selalu bersyukur dan menyampaikan salam.

\section{DAFTAR PUSTAKA}

Agusti, D., Rahmatan, H., Sulastri. (2019). Pengembangan Modul Pembelajaran Sistem Reproduksi Berazaskan Al-Quran/Hadis untuk Meningkatkan Motivasi dan Hasil Belajar Peserta Didik. Journal Edusains. Vol. 11 (1).

An-Najjar, Z. (2011). Sains Dalam Hadis (Mengungkap Fakta Ilmiah Dari Kemukjizatan Hadis Nabi). PT: Amzah . Jakarta.

Bahtiar, S. et.all. (2018). The spiritual and social attitudes of students towards integrated problem based learning models. Journal Issues in Educational Research. Vol. 28 (2).

Febriana, L.C., Sulur \& Yudyanto. (2014). Pengembangan Lembar Kerja Siswa (LKS) Fisika Materi Tekanan Mencakup Ranah Kognitif, Afektif, dan Psikomotor sesuai Kurikulum 2013 untuk Siswa SMP/MTs. Jurnal Program Studi Fisika FMIPA Universitas Negeri Malang.

Hafiz, A. et.all. (2019). Bilangan Pecahan dalam Al-Quran dan Hadits. Prosiding Sendika. Vol. 5 (1).

Hake, R.R. (1998). Interactive-Engagement vs Traditional Methods: a six-thousand-student Survey of Mechanics Test Data for Introductory Physics Courses. American Journal of Physics. 66 (1).

Irwansyah, M., Nurfahurrahmah \& Arifin. (2018). Pengembangan Perangkat Pembelajaran IPA Terpadu Berorientasi Model PBL dengan Pendekatan Integratif untuk Meningkatkan Kompetensi Sikap dan Pengetahuan Siswa. Oryza Jurnal Pendidikan Biologi. Vol. 7 (1).

Jamilah. et.all. (2014). Integration of Islamic Input in Medical Curriculum - Universiti Sains Islam Malaysia (USIM). The International Medical Journal of Malaysia. Vol. 13 (2).

Makmun, M.N. (2014). Pengembangan Pembelajaran IPA (Sains) dan IPS di Madrasah Ibtidaiyah (Berbasis Integrasi Interkoneksi). TERAMPIL: Jurnal Pendidikan dan Pembelajaran Dasar. Vol. 1 (1). 
Mulyasa. (2013). Pengembangan dan Implementasi Kurikulum 2013. Bandung: PT: Remaja Rosda Karya.

Niimati, R.A \& Mursalin. (2018). Penerapan Bahan Ajar Fisika Berbasis Nilai-Nilai AlQur'an pada Konsep Gerak Melingkar untuk Meningkatkan Hasil Belajar Siswa Kelas X Madrasah Aliyah. Prosiding Seminar Nasional Quantum. Pendidikan Fisika UAD.

Salafudin. (2019). Penanaman Nilai Nilai Pendidikan Islam melalui Pembelajaran Matematika. HIKMATUNA: Journal for Integrative Islamic Studies. Vol. 5 (1).

Sosilowati, S. 2017. Pengembangan Bahan Ajar IPA Terintegrasi Nilai Islam untuk Meningkatkan Hasil Belajar IPA. Jurnal Inovasi Pendidikan IPA. Vol. 3 (1).

Susanti, N \& Djukri, D. (2018). Pengembangan Modul Biologi Materi Pokok Ekosistem Berbasis Aktivitas Siswa di Pondok Pesantren untuk Menanamkan Sikap Spiritual dan Kemandirian Siswa. Jurnal Inovasi Pendidikan IPA. Vol. 4 (1). 